\title{
THE POLLCIES AND MEASURES FOR SELF-EMPLOYMENT AND ENTREPRENEURSHIP IN MACEDONIA AMONG THE ROMA GOMMUNITY
}

\author{
Vesna Garvanlieva ANDONOVA ${ }^{a *}$, Marjan NIKOLOV ${ }^{b}$, Deniz \\ SELMANI ${ }^{c}$, Igor MITEVSKI ${ }^{d}$, Fatima OSMANOVSKA KUNDOVSKA ${ }^{\mathrm{e}}$ \\ ${ }_{a, b), c, d)}$ Center for Economic Analyses, Skopje, Republic of Macedonia \\ e) Initiative for Development and Inclusion of the Communities
}

Please cite this article as:

Article History:

Andonova, V.G., Nikolov, M., Selmani, D., Mitevski, I., Osmanovska Kundovska, F., 2017. The policies and measures for self-employment and entrepreneurship in Macedonia among the Roma community. Review of Economic Studies and Research Virgil Madgearu, 10(2), pp.5-26.

doi: 10.24193/RVM.2017.10.07.

\begin{abstract}
Roma community are vulnerable to both the economic and social shocks which hamper their participation within the national employment policies. Relatively few Roma use the state's programs for employment and entrepreneurship enhancement despite their willingness. Even though the access to these programs is still low, the perception among a significant number of the Roma entrepreneurs (formal and informal) is that the offered programs may help in the development of their businesses. The research reviews and analyzes the policies for socio-economic access and inclusion of Roma in Macedonia within the context of entrepreneurship, covering formal businesses and informal businesses as well as considering a gender perspective, and regional variation of the usage of the policy measures.
\end{abstract}

Key words: othering, entrepreneurship, Roma, Chi-Square test, labor market. JEL Classification: $J_{15}$

(C) 2017 Alma Mater Publishing House. All rights reserved.

* Corresponding author. E-mail address: vesna_nl@yahoo.com. 


\section{References}

1. Agresti, A. and Kateri, M., 2011. Categorical Data Analysis. Berlin: Springer.

2. Bonachich, E., 1973. A theory of middleman minorities. American Sociological Review, 38(5), pp.583-594.

3. Brons, L.L., 2015. Othering, an analysis. Transcience, a Journal of Global Studies, 6(1), pp.69-90.

4. Center for Economic Analyses (CEA), 2016. Review of the policy for entrepreneurship in Macedonia: With special reference to Roma. [pdf] Available at: http://cea.org. mk/wp-content/uploads/2016/o7/o.-Pregled-na-politiki-TSEA-IRIZ-za-Veb.pdf.

5. Commission of the European Communities, 2003. Green Paper Entrepreneurship in Europe. [pdf] Available at: http://ec.europa.eu/invest-in-research/pdf/download_ en/entrepreneurship_europe.pdf.

6. Decade of Roma Inclusion Secretariat Foundation, 2015. Roma Inclusion Index 2015. [online] Available at http://www.rcc.int/romaintegration2020/files/user/ docs/Roma\%20Inclusion\%20Index\%202015.pdf.

7. Employment Agency of the Republic of Macedonia, 2013, 2014, 2015. Annual Report, 2014, 2015, 2016. [online] Available at: http://www.avrm.gov.mk/ godishni-izveshtai.nspx.

8. European Commission, 2016. Commission staff working document, The former Yugoslav Republic of Macedonia 2016 Report. [pdf]Available at: https://ec.europa.eu/ neighbourhood-enlargement/sites/near/files/pdf/key_documents/2016/20161109_ report_the_former_yugoslav_republic_of_macedonia.pdf.

9. Gibb, A., 2000. SME Policy, Academic Research and the Growth of Ignorance, Mythical Concepts, Myths, Assumptions, Rituals and Confusions. International Small Business Journal, 8(3). pp.13-35.

10. Hauke, J. and Kossowski, T., 2011. Comparison of values of Pearson's and Spearman's Coefficients on the same sets of data. Questiones Geographicae, [e-joirnal] 30(2), pp.87-93. https://doi.org/10.2478/v10117-011-0021-1.

11. Kligman, G., 2001. On the social construction of "otherness" identifying "the Roma" in post-socialist communities. Review of Sociology, 7(2) pp.61-78.

12. Lundstrom, L. and Stevenson, A.L., 2005. Entrepreneurship Policy: Theory and Practice. International Studies in Entrepreneurship. New York: Springer.

13. McGarry, A., 2012. The dilemma of the European Union's Roma policy. Critical Social Policy, 32(1), pp. 126-136. https://doi.org/10.1177/0261018311425201.

14. Mengstie, S., 2011. Constructions of "otherness" and the role of education: The case of Ethiopia. The Journal of Education, Culture, and Society, [e-journal] 2, pp.7-15. Available at: http://cejsh.icm.edu.pl/.

15. Ministry of Labour and Social Policy, Strategic documents from the decade of Roma Inclusion, Republic of Macedonia, 2014. With Action Plans, Available through: http:// www.mtsp.gov.mk/dokumenti-642e295b-69e3-4291-acb1-2ce6beb8cdd8.nspx.

16. Ministry of Labour and Social Policy in cooperation with the National Coordinator of the Decade and Strategy for Roma, 2014. Strategy for Roma in Macedonia from 2014 to 2020. Available at: https://goo.gl/8dJwJH.

17. Ministry of Labour and Social Policy, 2016. Operational Plan for active programs and measures for employment and services of the labor market for 2016. Available at: https://goo.gl/4SGt5N. 
18. Official Gazette of the RM No. 5/2002., Law on Local Self-Government.

19. O'Higgins, N. and Kirevska, S., 2012. Independent Evaluation of UNDP Program. Self-employment II-V and Technical Assistance to Support the Government Operational Plan for Active Labor Market Measures. UNDP, Country office FYR Macedonia. Available at: https://erc.undp.org/evaluation/evaluations/ detail/4824.

20. Ramadani, V. and Rexhepi, G., 2014. Ethnic entrepreneurship in Macedonia: the case of Albanian entrepreneurs. International Journal of Entrepreneurship and Small Business, 23(3), pp.313-335.

21. Redzepi N., 2011. Chronic Deception: A Brief Analysis of Roma Policies in Macedonia. Available at: http://www.romadecade.org/egy-cikk.php?hir_id=8481.

22. Ringold, D., Orenstein, M.A. and Wilkens, E., 2005. Roma in an expanding Europe: Breaking the poverty cycle. The World Bank. Available at: http://siteresources. worldbank.org/EXTROMA/Resources/roma_in_expanding_europe.pdf.

23. Rostas, I., Rovid, M. and Szilvasi, M., 2015. On Roma Civil Society, Roma Inclusion, and Roma Participation. European Roma Rights Centre. Available at: https:// www.academia.edu

24. Schumpeter, A.J., 1934. Theory of Economic Development: An Inquiry into Profits, Capital, Credit, Interest, and the Business Cycle. Cambridge: Harvard University Press.

25. Tavani, C., 2012. Collective rights and the cultural identity of the Roma: a case study of Italy. Leiden: Martinus Nijhoff.

26. The municipality of Bitola, 2014. Strategy for Local Economic Development 20142018. Available at: https://goo.gl/PZSMdR.

27. The municipality of Prilep, 2014. Strategy for Local Economic Development 20142020. Available at: https://goo.gl/2P4rdK.

28. The municipality of Suto Orizari, 2014. Strategy for Local Economic Development 2014-2O2O. Available at: https://goo.gl/zCzjSN.

29. UNDP/WB regional survey on Roma communities, 2011. Available at: http://www. eurasia.undp.org. 